ИСТОРИЈСКИ ЧАСОПИС, књ. LXIX (2020) стр. 81-97

THE HISTORICAL REVIEW, vol. LXIX (2020) pp. 81-97

УДК: 68(497.11)"04/14"

DOI: $10.34298 / \mathrm{IC} 2069081 \mathrm{~F}$

\title{
Александра ФОСТИКОВ*
}

Историјски институт

Београд

\section{МОБИЛНОСТ ЗАНАТЛИЈА НА ТЕРИТОРИЈИ СРЕДЊОВЕКОВНЕ СРБИЈЕ}

\begin{abstract}
Ancmpaкm: Током периода средњег века, који припада дугом аграрном добу, занатство се развијало и гранало у складу са сопственим чиниоцима развоја, што је утицало и на диференцијацију и на стратификацију самих занатлија. Како би мобилност ових произвођача на територији средњовековне Србије била детаљније истражена, на податке из изворног материјала примењена је постојећа подела типова покретљивости, усклађена са датим временом. Тако је и поред скромног процента поименично познатих занатлија било могуће установити да су оне биле мобилне, као и указати на поједине типове покретљивости, било из угла друштвене географије, друштвено социјалне стратификације или померања унутар породице.

Кључне речи: занатство, занатлије, мајстори, мобилност, средњи век, Србија.

Abstract: During the Middle Ages, which belong to the long agrarian age, crafts developed and branched in line with own factors of development, influencing both the differentiation and stratification of craftsmen. To examine in more detail the mobility of these producers in the territory of medieval Serbia, the existing division of mobility types, harmonised with the given time, was applied to the data from source material. Thus, despite the modest percentage of craftsmen known by name, it was possible to establish that they were mobile and highlight individual types of mobility, either from the aspect of social geography, social stratification or shifts within families.
\end{abstract}

Keywords: crafts, craftsmen, mobility, Middle Ages, Serbia.

Мобилност не само занатлија, већ ни професионалних делатника (laboratores) у средњем веку није детаљније разматрана све до новијег времена, у ком економска, али и социјална историја добијају на значају. ${ }^{1}$

*aleks.fostikov@gmail.com

${ }^{1}$ P. O. Long, The Annales and the History of Technology, Technology and Culture 46/1 (2005) 177-186; В. Станић, Франиуска историографија у ХХ веку-изазов мултидисииплинарности, Синтезис: часопис за хуманистичке науке и друштвену стварност I/1 (2009) 203-217, са ст. лит. 
Истовремено отварање нових тема и повезивање наука довели су и до нешто другачијег методолошког приступа. Преузети модели и типологије из других наука, уз извесна прилагођавања, примењени су тако и ради разврставања доступних историјских података у складу са појединим постављеним питањима. ${ }^{2}$ Такав развој историјске науке довео је и до отварања истраживања о начинама мобилности средњовековног друштва, а посебна пажња посвећена је друштвеној покретљивости. ${ }^{3}$

Када се говори о средњовековним занатлијама, па и на територији тадашње српске државе, најпре треба истаћи да су у питању не само професионални делатници, већ да је у питању група произвођача, која се одваја како у обичајном праву, тако и у каснијем законодавству. ${ }^{4}$ Током тог периода занатство се развијало и гранало, у складу са сопственим чиниоцима развоја, што је утицало и на диференцијацију и на стратификацију самих занатлија. Тако на њих у датом периоду утичу сви они чиниоци који се могу везати и за развој самог занатства законодавство, урбанизација, ниво вештине и знања, технолошки развој, те микро и макро миграције, па чак и циркулација становништва на линији рурално-урбано, односно центар и периферија, а од значаја су и брачни савези. ${ }^{5}$ Ипак, та групација унутар себе је вишеструко подељена

${ }^{2}$ Преглед историјских теорија и модела у новије време даје Питер Берк, који истиче и питање улоге, класе, статуса или мобилности - P. Berk, Istorija i društvena teorija, Beograd 2002.

3 За концепте, постојеће тезе и могућности истраживања, као и са ст. лит.: D. Herlihy, Three Patterns of Social Mobility in Medieval History, The Journal of Interdisciplinary History 3/4 (1973) 623-647; P. Berk, Istorija i društvena teorija, 70-73; J. Padgett, Open Elite? Social Mobility, Marriage, and Family in Florence, 1282-1494, Renaissance Quarterly 63/2 (2010) 357-411; S. Carocci, Social Mobility and the Middle Ages, Continuity and Change, A Journal of Social Structure, Law and Demography in Past Societies 26 (2011) 367-404; M. E. Smith, Peasant Mobility, Local Migration and Premodern Urbanization, World Archaeology 46/4 (2014) 516-553. У таквим манирима питању друштвене мобилности у Италији посвећен је у најновије време и посебан зборник радова, који је укључио и истраживање покретљивости и у другим средњовековним регионима у оквиру првог дела: Social Mobility in Medieval Italy (1100-1500), ed. by S. Carocci and I. Lazzarini, Roma 2018, passim.

${ }^{4}$ А. Фостиков, Занатство средњовековне Србије, Историјски институт, Београд, Народни музеј Пожаревац, SD Press, Смедерево 2020, 11-19.

5 J. J. Spengler, Economic Factors in Economic Development, The American Economic Review 47/2 (1957) 42-56; B. F. Hoselitz, Noneconomic Factors in Economic Development, The American Economic Review 47/2 (1957) 28-41; Ф. Бродел, Списи о историји, Београд 1992, 189-202; S. Đurović, Istorija i ekonomske nauke, Treći program Radio Beograda III/2 (1971) 402-405; S. M. Afghah, The Effect of Non-economic Factors in Economic Development in Third World Countries: A Case Study of Iran, PhD Thesis, University of Birmingham, UK, April 1998, 44-64. 
у складу са друштвеним поретком, а статус појединца зависио је од питања да ли је и коме поједини занатлија и подређен, осим врховном господару, као и од места радюе, односно врсте насеља у ком је боравио. Самим тим, занатлије је могуће поделити и на: руралне и урбане, сакралне и световне, владарске или властеоске, а могу се као посебна категорија издвојити и рудничке. ${ }^{6}$

Са друге стране, као основни типови покретљивости истичу се: хоризонтална, вертикална и просторна, а као додатни и: унутаргенерацијска и међугенерацијска, при чему се мора имати у виду и да једна другу не искључују. Додатно, покретљивост једне групе и појединаца унутар исте, могу се разматрати из угла друштвене мобилности у оквиру постојеће стратификације, али и просторне са аспекта друштвене географије. ${ }^{7}$ Ове, као и само занатство, делимично расветљавају бројни изворни подаци различитог типа и порекла, међу којима и називи. Иако су извори оскуднији и фрагментарнији за територију српских средњовековних земаља, на значају добијају у оквиру њиховог разматрања у општем контексту. ${ }^{8}$

Мада је хоризонтална мобилност уско дефинисана као покретљивост која подразумева прелазак са једне на другу позицију, а без значајне промене у статусу, треба истаћи да ову у дато време прате и просторна, па и вертикална кретања, која утичу и на раслојавање занатлија. Тако већ сам Закон мајсторија занатлије сврстава у властеоске подложнике, али и указује на могућа померања како у оквиру, тако и међу генерацијама, што доводи и до условног раздвајања браће, па се ова могу наћи међу

\footnotetext{
${ }^{6}$ Место занатске радње може се дефинисати и у односу према економском центру ком правно припада, врсти центра, те удаљености од централног насеља, или свог економског центра, при чему треба имати у виду да се као такви у оквиру властелинства могу издвојити и двор и манастир, а у оквиру урбано- руралних односа и град, трг, трговиште, али и село, заселак, као и сами урбани типови - Ј. Мргић, Проучавање „иентралних" насеља у историјској географији Византијског ияарства на Балкану и могућности примене нове методологије, Византијски свет на Балкану II, ур. Б. Крсмановић, Љ. Максимовић, Р. Радић, Београд 2012, 285-297, са ст. лит; А. Фостиков, Занатство средњовековне Србије у светлу три повеље из 14. века, БИГ 4 (2013) 52-53, 65 ; иста, Занатство средњовековне Србије, passim. О термину рудничке занатлије видети ниже.

${ }^{7}$ О типовима мобилности детаљније: P. Sorokin, Social Mobility, New York-London 1927 (reprint: Taylor \& Francis, 1998), passim; Social Mobility in Medieval Italy (1100-1500), ed. by S. Carocci and I. Lazzarini, Roma 2018, passim.

${ }^{8}$ G. Clark, N. Cummins, Y. Hao, D. D. Vidal, Surnames: A New Source for the History of Social Mobility, Explorations in Economic History 55 (2015) 3-24. Не само имена, већ и називи заната указују на диференцијацију заната и занатлија. А. Фостиков, Занатство средњовековне Србије, passim. Видети и ниже.
} 
мајсторијама, меропсима, те сокалницима, а како је указано посредно, у следећој генерацији и међу поповима. Додатно, и сама промена господара, или њихово пресељење, утицали су и на ниво привилегија. ${ }^{9}$

Истовремено, и поред условног затварања слоја мајсторија унутар поседа, одвија се и преношење знања и занатског статуса са оца мајстора на сина, односно одабраног наследника заната: пасторка, ћерку - односно зета, али и у оквиру куће, у ком се и остала деца истом приучавају, што доводи и до појаве да се и већи број чланова исте фамилије, попут браће, јавља са истом професијом. Тако се више чланова једне породице јавља често у ковачком и градитељском занату. У оквиру урбаних конструкта и њима оријентисаног руралног залеђа, на тај начин долази и до појаве да се сродници јављају у истим радним улогама, а међу осталима сусрећу се и три брата кројача у Новом Брду, те мајстор и пасторак, мајстор и синовац, као и браћа мајстори непознате професије у одреду деспота Стефана 1402. године. Судећи бар према антонимима везаним за круг nomina professionalia, чија основна теза полази од могућности и да је у питању ознака за наследност сина-шегрта, или пак да се заснива на занимању важног претка, често оца, може се опазити и мобилност између генерација, која указује да долази и до промене основног заната, или бар његове варијације, па се и Бојко Златаревић бележи међу обућарима (у датом случају ц’нгарима) Призрена. ${ }^{10}$

Паралелно, одвија се и просторна мобилност, у виду унутрашњих наређених или самосталних миграција, на релацији стари - нови центар, те између руралне и урбане средине, али и вангранична кретања ради практиковања заната, односно стицања бољег материјалног статуса, па

\footnotetext{
9 Закон о мајсторијама регулисао је у основи радне обавезе, давања и права занатлија, као и питање наслеђивања њиховог статуса. Једини примерци сачувани су у Бањској (БX 1313-1316) и Дечанским повељама (ДХ I 1330, ДХ II 1330-31, ДХ III- после маја 1343 пре краја децембра 1345). За упоредни преглед одредби у изворима, са пописом старијих издања, видети: Р. Михаљчић, Закони у старим српским исправама, правни прописи, преводи, уводни текстови и објашњењ а, САНУ, Београд 2006, 29, 30, 33, 37, 38, 64, 71, $73,75,80,83,87$. За детаљну анализу одредби овог закона, видети: А. Фостиков, Занатство средњовековне Србије у светлу три повеље из 14. века, 53-55, 57.

${ }^{10}$ М. Динић, Из Дубровачког архива, I, Београд 1957, 40, 48, 73, 78; К. Мандић, Из долине Кашка-Дарје у Самарканд, Нови бехар 24 (Сарајево 1928) 400-404; С. Мишић, Т. Суботин-Голубовић, Светоарханђеловска хрисовуља, Београд 2003, 113, 143; Д. Ковачевић-Којић, Градски живот у Србији и Босни (XIV-XV), Београд 2007, 372, 375; А. Фостиков, Ковачки занат на тлу средњовековне Србије, БИГ 3 (2012) 114; иста, Занатство средьовековне Србије у светлу три повеље из 14. века, 55; А. Фостиков, В. Петровић, Прилог проучавағу војне улоге занатлија у средњовековној Србији, БИГ 5 (2014) 61; А. Фостиков, Занатство средњовековне Србије, 137.
} 
је чак и у територијалној мобилности вертикално кретање видљиво у оба смера. ${ }^{11}$ О релокацијама потребних занатлија, посебно градитеља, било поводом одређеног посла или трајним пресељењем по налогу господара, говоре и Дечанске повеље (ДХ II-III), те Светоарханђелска. Како је ова струка сама по себи претпостављала промену места боравка, исти су често били и чланови путујућих дружина. ${ }^{12}$ Према устаљеној пракси средњег века, мајстори су позивани не само ради изградње, већ и ради засељавања homo fabera, а пракса позивања, па чак првобитно и сељења, долазила је уз даривање одређених повластица, односно извесних ослобађања. ${ }^{13}$

Такође, опажају се и микро кретања - чак и на дневној основи. Занатлије из околних насеља долазиле су у град, из различитих потреба, па и ради кредитирања, а вероватно да су том приликом и продавале своје услуге и производе. На такву циркулацију мајстора на широј територији између појединих локација или унутар градског атара, између руралне средине и урбаног средишта, недвосмислено указује и трговачка књига Михаила Лукаревића, дубровачког трговца, који је тридесетих година XV века живео и пословао у Новом Брду. Занатлије, са правом слободе кретања, мењале су место боравка, па тако у појединим, посебно урбаним економским центрима, бораве и произвођачи из других већих насеља и градова, док истовремено појединци, одлазе у иностране центре. ${ }^{14}$

У извесним случајевима ради преношења појединог знања, зналци вештине слати су и у мисије код страних владара, или су долазили на

${ }^{11}$ О типовима просторног кретања: М. E. Smith, Peasant Mobility, 516-519. О вертикалној стратификацији, видети ниже.

${ }_{12}$ С. Мишић, Т. Суботин-Голубовић, Светоарханђеловска хрисовуља, 140; А. Фостиков, Занатство средњовековне Србије, са изворима и ст. лит., 108, 118-120. Видети и изнад нап. 9.

13 Тако повељом од 7. новембра 1427. Жигмунд позива занатлије Шопрона да се населе у Београду. А. Крстић, Београдско писмо краља Жигмунда грађанима Шопрона (7. новембар 1427. године), Мешовита грађа (Miscellanea) 33 (2012) 21-36; А. Веселиновић, Држава српских деспота, Београд 1995, 129, н. 78.

${ }^{14}$ М. Динић, Из Дубровачког архива, I, 1-2, и даље passim. Између осталих и ковач Никола Радетић одлази из Новог Брда у Софију, кројач Андрија у Кратово, златар Јован Прогоновић у Дубровник, златар Петар у Котор, кројач Радослав из Смедерева ради у Новом Брду. Веште ковничаре тражили су Дубровчани, као закупци призренске царине - а изгледа и ковнице, 1370. године у Новом Брду, док је велики број домаћих мајстора забележен касније, након пада српске државе под турску власт и у Дубровнику, па тако и 1471. године и Никола Србин bombardius - Д. Ковачевић-Којић, Градски живот, 379; Д. Динић-Кнежевић, Миграиије становништва из јужнословенских земаља у Дубровник током средњег века, Нови Сад 1995, 76-79; В. Иванишевић, Новчарство средюовековне Србије, Београд 2001, 55, 67; В. Јовановић, С. Ћирковић, Е. Зечевић, В. Иванишевић, В. Радић, Ново Брдо, Београд 2004, 48 (В. Јовановић); А. Фостиков, Занатство средюовековне Србије, passim. 
позив, посебно у случају ратне технологије. ${ }^{15}$ Ради ширења нових вештина, долазили су и на позив владара, господара или важне личности, а у појединим случајевима су и трајније насељавани. Међу таквим страним миграцијама, а од утицаја на развој заната, истиче се позната саска, ${ }^{16}$ а запажен је и долазак приморских мајстора. Ипак, присуство страних занатлија јаче је само у случају евентуалне новине, или тамо где је странац не само занатлија странац већ и трговац, као што је то био често случај Дубровчана. Останком истих и по неколико деценија, те стварања нових породица, свакако да је долазило до асимилације, те се након неколико генерација тешко може говорити о датом лицу као страном елементу, изузев можда у правно-судском смислу, који је очигледно коришћен и као изговор за умањење дажбина. Судећи према примерима попут помена седлара Милете Великшалића у Новом Брду, 1437. године, и домаћи занатлија због трговачких несугласица са Дубровчанима могао је да се нађе под општинском јурисдикцијом, у случају суђења са неким од дубровачких пословних партнера. ${ }^{17}$

15 За поједине примере слања или позивања помоћи у зналцима, видети и: М. Динић, Прилози за историју ватреног оружја у Дубровнику и суседним земљама, ГЛАС СКА 161 (1934) 83-84; Ђ. Петровић, Главно оружије епохе и оружари у земьи Стефана Вукчића Косаче, Српска проза данас. Косаче - оснивачи Херцеговине. Ћоровићеви сусрети прозних писаца у Билећи и Научни скуп историчара у Гацку, 20-22. септембар 2000, Просвјета, Билећа, Просвјета Гацко, Фонд „Владимир и Светозар Ћоровић“, Београд 2002, 518, 530, са изворима и ст. лит.; А. Фостиков, В. Петровић, Прилог проучавању војне улоге занатлија у средњовековној Србији, 60, 61, 66 са изворима и ст. лит.; А. Фостиков, Занатство средюовековне Србије, 88.

${ }^{16}$ А. Фостиков, Занатство средњовековне Србије, 37, 40, 79, 114, са ст. лит.

${ }^{17}$ А. Веселиновић, Дубровачко Мало веће о Србији (1415-1460), Београд 1997, 386. Исти Милета бележи се више пута у Новом Брду. Под истим презименом Velixalich јавља се и у књизи Лукаревића. Такође у одлукама већа, забележен је и под презименом Velisalich, а у прилог таквој идентификацији говори и да се у оба случаја јавља заједно ca Твртком обрађивачем коже (peliparius) у судским одлукама Малог већа. М. Динић, Из Дубровачког архива, I, 62; А. Веселиновић, Дубровачко Мало веће о Србији (14151460), 349, 386, и даље према регистру. Како је већина познатих занатлија по имену забележена у латинској грађи, посебно у одлукама Малог већа у вези са суђењима која су одржана на територији Српске деспотовине, или дужничким књигама и тестаментима, треба указати да су бар делом у питању домаћи становници, како то и случај Милете указује. Такође, подаци који упућују да се поједине занатлије налазе и у статусу дубровачких грађана, свакако наводе да су извесни правни слободни статус исте стекле још раније, а не треба занемарити ни да се називи cives и habitator бележе и у Сребреници, па и уз име једног ковача, Ратка (1437). Да они нису непознати ни у латинским актима српских владара, говори и повеља Ђурђа Бранковића, о потврди слободе грађанима Дебрецина. Мада је овај акт начињен према угарском обрасцу за један угарски град, ипак упућује на познавање система грађанства. С. Ћирковић, Из старог Дубровника: грађани рођени и грађани стечени, ИЧ 56 (2008) 21-37; Д. Ковачевић- 
Додатно крајем средњег века јавља се и расељавање пред турском опасношћу, што доводи до одлива оних највештијих, који одлазе у избеглиштво било са владарима, властелом или самостално. Тако се одвија и миграција у приморске, али и нове центре у унутрашњости, а део занатлија, вероватно да се сели и на новодобијене деспотске поседе ван српске државе. ${ }^{18}$

Коначно, ту је и она, можда најважнија, вертикална мобилност, која се одвијала у оба правца и која је повезана и са осталим врстама покретљивости. Давно је истакнуто да на друштвену мобилност овог типа утичу специјализација занимања, ниво вештине, власт и економска контрола, али и престиж, који указује на статус самог занимања, али делом и зависи од друштва и времена. У том смислу треба додатно разликовати и статус занимања, који се дефинише у оквиру своје диференцијације и стратификације, од мобилности и статуса појединог занатлије. ${ }^{19}$

Устројство првобитног мајсторског слоја мењало се током времена у оквиру властелинства. Да је ова категорија претпела унутрашњу стратификацију потврђују помени занатлија земљопоседника или оних са посебним повластицама. Ту су занатлије подложници са земљом, затим

Којић, Градски живот, 423-424; Н. Исаиловић, А. Фостиков, Повеља господина Ђурђа Бранковића којом потврђује слободе грађанима Дебречина (Биа, 1429, 5. мај), Мешовита грађа (Miscellanea) 33 (2012) 62, н. 20, са освртом на питање терминологије и ст. лит.; А. Фостиков, Занатство средюовековне Србије, 169-170.

${ }^{18}$ Проучавања миграције домаћег становништва у Угарску, као и детаљнија проучавања поседа српских владара на тлу исте, па и уопште институција и функционисања администрације домаћих господара у истој, тек су у новије време започета озбиљније, па тако посебна пажња није посвећена ни миграцији занатлија на угарске поседе, као ни у Угарску уопште, иако их је свакако било. О миграцијама у Угарску, расељавању и функционисању двора у новије време видети: С. Ћирковић, Сеобе српског народа у краљевину Угарску у XIV и XV веку, Сеобе српског народа од XIV до XX века. Зборник радова посвећен тристогодишњици Велике сеоба Срба, Београд 1990, 37-46; А. Крстић, Сеоска насеља у Подунављу и Посавини Србије и јужне Угарске у 15. и првој трећини 16. века, ИЧ 52 (2005) 165-194, са ст. лит.; А. Крстић, Деспот Бурађ Вуковић и закуп коморе у Нађбањи, ИЧ 64 (2015) 237-252, са ст. лит. Видети и изнад, нап. 15. За утицај српског наслеђа на угарске пећњаке: А. Фостиков, Занатство средњовековне Србије, 132.

19 Док са једне стране стари занати нестају, нови се уздижу, а потребе свакодневнице и центра, као и захтеви господе дефинишу место датог заната или занатлије у оквиру структуре. М. B. Katz, Occupational Classification in History, The Journal of Interdisciplinary History 3/1 (1972) 65; D. J. Treiman, A Standard Occupational Prestige Scale for Use with Historical Data, The Journal of Interdisciplinary History 7/2 [Social Mobility in Past Time] (1976) 288, 290, 293, 300; S. Carocci, Social Mobility and the Middle Ages, 379-381. Видети и изнад, нап. 3, 7. О месту појединог заната: А. Фостиков, Занатство средњовековне Србије, passim. 
ту су мајсторска насеља, са селом у поседу, и коначно ту су и занатлије које у поседу имају и поједина села, као и работнике. ${ }^{20}$

Док ретки подаци о раду према уговору, проценту зараде ковача, уговореној цени рада, висини задужења или давању пореза у производима, могу да послуже за оквирно одређивање имућности, награђивање оних вештих и окупљање најдаровитијих, нешто детаљније бележе житија и даровнице. Тако су и мајстори Десин и син му Блаж били плаћени за изградњу Давидовице, а краљица Јелена приликом изградње Градца није штедела злата да исплати рад мајстора. И зидари задужбине кнеза Лазара, према народној традицији, богато су награђени за свој рад, а о тражењу најдаровитијих, па и сликара, за рад на Манасији деспота Стефана, говоре речи Константина Филозофа. ${ }^{21}$

Судећи према анализираним изворима већ у време Стефана Дечанског награђивање занатлија земљом није било неуобичајно. Тако је ковач Рудал земљу на Трстеној добио од претходника Стефана Душана, а ковач (вигањ) Његоје се јавља са својом земљом и правом да држи део Блата. Све ове занатлије су до својих поседа долазиле поклоном, а вероватно и откупом (куnљеница) као и други становници. О једном таквом процесу добијања баштине обавештавају нас примери протомајстора Георгија, као и зидара из Пнуће. Према ДХ II-III Георгије је са браћом село Манастирац добио у баштину од Стефана Дечанског као награду за рад и украшавање бројних цркви на српској земљи. То им је потврдио потом и цар Душан, наводећи да су радили на многим црквама у граду и около, као и на зидању дечанске трпезарије и пирга над портом, а који их је изгледа додатно даривао и селом Влахиње. Да су занатлије поседовале

\footnotetext{
${ }^{20}$ Тако се јављају и ковачи са својим сопственим радионицама, топионицама и самоковима, као и они који исте узимају у закуп. А. Фостиков, Занатство средњовековне Србије у светлу три повеље из 14. века, 51-69. Видети и ниже. О мајсторским насељима као посебном типу економског центра, у ком раде и живе занатлије специјализоване у истој вештини, видети: Г. Томовић, Средњовековна мајсторска села на размеђи сеоског и градског друштва, Српско село. Могућности и даљи правци истраживања, Београд 2003, 7-17; А. Фостиков, Занатство средюовековне Србије у светлу три повеље из 14. века, 57, 65.

${ }_{21}$ Животи краљева и архиепископа српских, 75-76; Константин Филозоф, Житије деспота Стефана Лазаревића, Стара српска књижевност у 24 књиге, књ. 11, Београд 1989, 103-104; Д. Ковачевић-Којић, Градски живот, 376, 379; А. Фостиков, Ковачки занат, 114-115; иста, Занатство средњовековне Србије, 123-124. R. Mihaljčić, Lazar Hrebeljanović. Istorija, kult, predanje, Beograd 1984, 196; Т. Стародубцев, Сликари задужбина Лазаревића, ЗРВИ 43 (2006) 359-363. Интересантно је да иста песма о зидању Раванице, сем богатог даривања, памти и да су надзорници градње Југовићи закидали мајсторе на обећаној надокнади, уп. Д. Лапчевић, Селски занати и занатлије y Немањићкој држави, Економист - орган Друштва за социјалну и економску политику 5/1 (Београд 1925) 24-25.
} 
своја села и у оквиру световних поседа илуструје и повеља цара Уроша из 1363. године. Таква мобилност мајстора у оквиру друштвене стратификације говори нам да је постојало раслојавање не само међу сеоским становништвом, него и у оквиру категорије мајсторија. Поседовање земље, а посебно села у виду својине или баштине, доказује да је већ средином 14. века, ако не и раније, део мајсторија улазио у слој властеличића, на шта је својевремено указао још А. Соловјев. ${ }^{22}$

У урбаним центрима, они бољег статуса, заједно са домаћим трговцима, постају и основа развоја српског грађанског слоја, а попут крупних трговаца и поједине занатлије истичу се својим богатством и поседом непокретне имовине у граду, или чак у више градова. О угледу појединаца и њиховом статусу у свету приморских градова, попут Дубровника, али и једног урбаног центра попут Призрена, говоре и подаци о појави занатлија као сведока на актима властеле и обласних господара. Тако се као сведоци на разрешници Балишића Дубровчанима за призренску царину (1374) јављају и Радослав мачар и Прибил, златар, док се као сведок у писму челника Милоша Повића Општини (пре септембра 1369) бележи Радоје златар, Дубровчанин. Коначно учешће једног Ташнаревића у настанку Законика деспота Стефана, указује на могуће место, ако не самог занатлије, онда његовог изданка. ${ }^{23}$ Такође, увиђа се и покретљивост унутар истог смера, па се према нивоу знања те вештине издвајају поименице оне познате занатлије, поједини златари, оружари, али и кројачи, бомбардијери или часовничари, попут монаха Лазара, а неке од њих и усмена традиција памти. ${ }^{24}$

${ }^{22}$ ДХ II, 45, 58-59 ф. 50, 62; ДХ III, 120 ф 59, 128 ф 67; ДХ ІІІ а, 262; С. Мишић, Т. Суботин-Голубовић, Светоарханђеловска хрисовуља, 109, 110, 138-139, 140; М. Шуица, Повеља иара Уроша о замени поседа између кнеза Војислава и челника Мусе, ССА 2 (2003) 146, 150, 154-155; А. Соловјев, Једна српска жупа за време царства, Гласник Скопског научног друштва III (1928) 34-35; А. Фостиков, Занатство средњовековне Србије у светлу три повеље из 14. века, 57.

${ }^{23}$ М. Пуцић, Споменици србски, II, Београд 2007², 26, 27 бр. 32-33; Љ. Стојановић, Старе српске повеље и писма, I, Београд-Сремски Карловци 1929, 108 бр. 110 (1374); Б. Марковић, Закон о руднииима деспота Стефана Лазаревића. Превод и правноисторијска студија, Споменик САНУ CXXVI. Одељење друштвених наука 24 (1985) 13; А. Фостиков, Занатство средњовековне Србије, 195, 199 н. 452.

${ }^{24}$ Тако традиција памти и Новака ковача и Радета неимара, а извор бележи и Божидара, личног кројача Калојана. А. Фостиков, Занатство средюовековне Србије, 29, 44-45 53, 116, 117, 218 н. 65, 109, 282, и passim. О пракси потражње и прибележавања вештог мајстора, овде звоноливца Ханса, видети: А. Крстић, Два необјављена латинска писма деспота Стефана Лазаревића, Иницијал. Часопис за средњовековне студије 3 (2015) 197-209. О монаху Лазару, сасвим недавно, писао је А. Узелац, Лазар Светогораи српски монах и часовничар између историје и мита, БИГ 10 (2019) 77-90. 
Подаци о удруживању и сарадњи занатлија, како градитеља, тако и осталих, па и унутар домаћих центара, познати су у великом броју преко латинске, посебно дубровачке грађе, која указује и на сарадњу и домаћих произвођача међусобно, али и са Дубровчанима и осталим странцима ради профита, те вероватно у бар појединим случајевима, и ради стварања трговачког артикла, па се између осталих примера јавља и сарадња неколицине шустера, или пак једног седлара и представника кожарске струке, о којој се може наслутити на основу података о међусобном гарантовању истих лица. По подацима у књизи Лукаревића, занатлије Новог Брда нису се према имовинском статусу разликовале од стручњака запослених у рударству, а њихова задужења су и сличне висине..$^{25}$ Такође, на основу ове књиге може се запазити и орођавање између мајсторских кућа, па је тако и Никола клобучар, зет протомајстора ${ }^{26}$ а на основу ширег опуса стране грађе уочити и паралела о издвајању рудничких занатлија. ${ }^{27}$

Ипак, док део занатлија формира не само виши, него и нижи градски слој заједно са ситним трговцима, а представници појединих заната

${ }^{25}$ М. Динић, Из Дубровачког архива, I, passim. Да су ови износи сличне вредности установила је својевремено још Д. Ковачевић-Којић. Иста, Градски живот, 379. Удруживања је било и међу рударима као и трговцима, који су често ступали у разне врсте друштава, те занатлијама, које у урбаним центрима, сем међусобно у појединим случајевима, сарађују свакако на трговачким основама и са другим професијама - А. Веселиновић, Дубровачко Мало веће о Србији (1415-1460), 386, такође и passim; А. Фостиков, Занатство средьовековне Србије, passim.

${ }^{26}$ М. Динић, Из Дубровачког архива, I, 66; А. Фостиков, Занатство средњовековне Србије, 169, 199 н. 389.

27 Термин рудничке занатлије односи се на занатлије које су радиле у рударским градовима, и за саме руднике. Судећи према законику деспота Стефана, као и чешкој верзији законика о рудницима, у складу са потребама рударства поједини занати и њихов рад, као и производ посебно су третирани, а њихови представници имали су и прописану плату, као и време рада. У извесним случајевима, у самом закону о рудницима и у турској верзији закона из 1488. године користи се и термин ковач руднички. Значај рудничких занатлија посебно металуршке струке можда најбоље изражава да су представници ковачке групе занимања своје место нашли и у рударској цркви - катедрали Св. Барбаре у Кутној Хори (Чешка), где је представљен и процес ковања. Интересантно је приметити и да се у верзијама Ius regale montanorum, како оној латинској, тако и чешкој, управо уз урбураре и хутмане јављају као лица од значаја и рударске занатлије, посебно дрводељске, односно грађевиснко-тесарске струке. Б. Марковић, Закон о руднииима деспота Стефана Лазаревића, 20-23 чл. 16, 17, 23, 51, 52, VI, IX, XIII, XV, XVII; H. Jireček, Codex juris Bohemici, Aetatem přemyslidarum continens I, Pragae 1867, 268, 295-296, 304, 310-311, 315. XIX-4, 352, XVI. 1-16; J. Bílek, Ius regale montanorum, aneb, Právo královské horníkuov, Kutná Hora : Kuttna 2000, 19 (22), 21 (4-3), 33 (12/8 чл. 1-5), 34 IX. 10-12, 35-36 XII. 1-16; 38 XV 4, 41 n. 115 - II. 14, 55 (Сар. I. 18). А. Фостиков, Ковачки занат, 111, 115, са изворима и ст. лит.; А. Фостиков, Занатство средњовековне Србије, 46, 51, 169 н. 114, 387. 
постају не само грађани, већ и трговци, долази и до пораста броја оних мање имућних, ситних произвођача, који директно раде не само за господара, већ и за појединог мајстора, као испомоћ у радионици. Додатно, треба имати у виду и да се обрађивачи влакна генерално сврставају у инфраструктуру радника у градовима, који се практично најмање плаћају, а међу њима и ткачи, иза којих се према сиромаштву бар у Западној Европи налазе само надничари и самостално упослене жене, без посебног знања. Ипак, док се поједине побуне масовне занатске радне снаге или покушаји да се у радним законима нешто промени бележе у страним изворима, а посебно у центрима где је производња изузетно развијена, домаћи извори сем побуне среброделаца у Сребреници (1427), не помињу друге изгреде, нити доносе податке који би указали на детаљнију стратификацију занатлија, а посебно у улози помоћника или шегрта. ${ }^{28}$

Сви ови подаци указују да је све типове мобилности могуће макар делимично испратити и на тлу средњовековне Србије. Међутим, при оцени улоге и друштвено социјалног положаја, као и типова његове покретљивости, мора се увек имати у виду да је homo faber, не само важан производни чинилац економије доба алата, већ и чинилац технолошког напретка у времену које обилује не само ширењем вештина и знања, већ и бројним проналасцима, а појединца мајстора заната издваја његова вештина.

Подаци о укључивању племства и властеле у трговину и рударске послове у градовима доводе и до једног питања, које за сада мора остати и отворено - да ли се у извесним случајевима и занатлија у граду у унутрашњости, осим приближавања племсту у смислу економске моћи, може наћи и у статусу племића, онако како се у оквиру властелинства могао наћи у статусу властеличића, те којим би путем био и укључен у исти слој. ${ }^{29}$

\footnotetext{
28 Лоше материјално стање и тешки услови рада доводе до покрета помоћника против мајстора још крајем 13. века. J. Kulischer, Opća ekonomska povijest srednjega i novoga vijeka, Zagreb 1957, 181, 215-217. О лошем положају радника на дну инфраструктуре сукнарства у Дубровнику: J. Lučić, Gospodarsko-drustveni odnosi u Dubrovniku u Stojkovićevo vrijeme (1392-1442), Historijski zbornik 38/1 (1985) 105-106. О побуни и термину среброделац: Комстантин Филозоф, Житије деспота Стефана Лазаревића, 122; А. Фостиков, Златарски занат у средњовековној Србији, Споменица академика Милоша Благојевића (1930-2012), одг. ур. С. Мишић, Филозофски факултет, Центар за историјску географију и историјску демографију, Београд 2015, 173-174; иста, Занатство средњовековне Србије, 62-63, н. 159, са ст. лит.

${ }^{29}$ Извесни случајеви грађанина племића, рударских експерата још се разматрају у литетратури - В. Петровић, Друштвено раслојавање у српским средњовековним рударским градовима, Наша прошлост 12 (Краљево 2011) 83-84, са ст. лит.; уп. М. Ивановић,
} 


\section{Скраћенице - Abbreviations}

БХ-Повеља краља Милутина манастиру Бағска-Светостефанска хрисовуља, књ. 2. Фототипије издања и пратеће студије, ур. Ђ. Трифуновић, Приштина, Београд 2011, $17-$ 39, 117-128.

ДХ I - М. Грковић, Прва хрисовуља манастира Дечани, Београд, Дечани, Приштина 2004, 64-81, 85-103.

ДХ II - С. М. Милојевић, Дечанске хрисовуље, Гласник СУД 12 (1880) 1-68.

ДХ III - С. М. Милојевић, Дечанске хрисовуље, Гласник СУД 12 (1880) 69-142.

ДХ ІІІ а - П. Ивић, М. Грковић, Дечанске хрисовуље, Нови Сад 1976, 143-286.

„Добри људи” Новобрдског законика деспота Стефана Лазаревића, ИЧ 64 (2015) 177 178. О новом племству или пучкој властели, детаљније P. Živković, Ekonomsko socijalne promjene u bosanskom društvu u XIV i XV stoljeću (pojava građanske klase i novog plemstva), Tuzla 1986, passim; Z. Pešorda Vardić, „Pučka vlastela“: Društvena struktura dubrovačke bratovštine Sv. Antuna u kasnom srednjem vijeku, Povijesni prilozi 33 (2007) 215-236. 


\section{ЛИСТА РЕФЕРЕНЦИ - LIST OF REFERENCES}

\section{Извори - Primary Sources}

Bílek J., Ius regale montanorum, aneb, Právo královské horníkuov, Kutná Hora 2000.

Jireček H., Codex juris Bohemici: Aetatem přemyslidarum continens I, Pragae, 1867.

Веселиновић А., Дубровачко Мало веће о Србији (1415-1460), Београд 1997. [Veselinović A., Dubrovačko Malo veće o Srbiji (1415-1460), Beograd 1997]

Динић М., Из Дубровачког архива, I, Београд 1957. [Dinić M., Iz Dubrovačkog arhiva, I, Beograd 1957]

Исаиловић Н., Фостиков А. Повеља господина Ђурђа Бранковића којом потврђује слободе грађанима Дебрецина (Биа, 1429, 5. мај), Мешовита грађа (Miscellanea) 33 (2012) 57-68. [Isailović N., Fostikov A., Povelja gospodina Đurđa Brankovića kojom potvrđuje slobode građanima Debrecina (Bia, 1429, 5. maj), Mešovita građa (Miscellanea) 33 (2012) 57-68]

Грковић М., Прва хрисовуља манастира Дечани, Београд, Дечани, Приштина 2004, 64-81, 85-103. [Grković M., Prva hrisovulja manastira Dečani, Beograd, Dečani, Priština 2004, 64-81, 85-103]

Животи краљева и архиепископа српских, написао архиепископ Данило и други, на свијет издао Ђ. Даничић, Загреб 1866. [Životi kraljeva i arhiepiskopa srpskih, napisao arhiepiskop Danilo i drugi, na svijet izdao Đ. Daničić, Zagreb 1866]

Ивић П., Грковић М., Дечанске хрисовуље, Нови Сад 1976, 143-286. [Ivić P., P. Grković P., Dečanske hrisovulje, Novi Sad, 1976, 143-286]

Константин Филозоф, Житије деспота Стефана Лазаревића (Повест о словима (Сказаније о писменех) - Житије деспота Стефана Лазаревића), Стара српска књижевност у 24 књиге, књ. 11, Београд 1989. [K. Filozof, Žitije despota Stefana Lazarevića (Povest o slovima (Skazanije o pismeneh) -- Žitije despota Stefana Lazarevića), Stara srpska književnost u 24 knjige, knj. 11, Beograd 1989]

Крстић А., Београдско писмо краља Жигмунда грађанима Шопрона (7. новембар 1427. године), Мешовита грађа (Miscellanea) 33 (2012) 21-36. [A. Krstić, Beogradsko pismo kralja Žigmunda građanima Šoprona (7. novembar 1427. godine), Mešovita građa (Miscellanea) 33 (2012) 21-36]

Крстић А., Два необјављена латинска писма деспота Стефана Лазаревића, Иницијал. Часопис за средњовековне студије 3 (2015) 197-209. [A. Krstić, Dva neobjavljena latinska pisma despota Stefana Lazarevića, Inicijal. Časopis za srednjovekovne studije 3 (2015) 197-209]

Мандић К., Из долине Кашка-Дарје у Самарканд, Нови бехар 24 (Сарајево 1928) 400404. [Mandić K., Iz doline Kaška-Darje u Samarkand, Novi behar 24 (Sarajevo 1928) 400-404]

Марковић Б., Закон о рудницима деспота Стефана Лазаревића. Превод и правноисторијска студија, Београд 1985. [В. Marković, Zakon o rudnicima despota Stefana Lazarevića. Prevod i pravno-istorijska studija, Beograd 1985]

Милојевић С. М., Дечанске хрисовуље, Гласник СУД 12 (1880) 1-68. [Milojević S. M., Dečanske hrisovulje, Glasnik SUD 12 (1880) 1-68]

Милојевић С. М., Дечанске хрисовуље, Гласник СУД 12 (1880) 69-142. [Milojević S. M. Dečanske hrisovulje, Glasnik SUD 12 (1880) 69-142]

Михаљчић Р., Закони у старим српским исправама, правни прописи, преводи, уводни текстови и објашњења, Београд 2006. [R. Mihaljčić, Zakoni u starim srpskim ispravama, pravni propisi, prevodi, uvodni tekstovi i objašnjenja, Beograd 2006]

Мишић С., Суботин-Голубовић Т., Светоарханђеловска хрисовуља, Београд2003. [Mišić S., Subotin-Golubović T., Svetoarhanđelovska hrisovulja, Beograd 2003] 
Повеља краља Милутина манастиру Банска-Светостефанска хрисовуља, књ. 2. Фототипије издања и пратеће студије, ур. Ђ. Трифуновић, Приштина, Београд 2011, 17 39, 117-128. [Povelja kralja Milutina manastiru Banjska-Svetostefanska hrisovulja, knj. 2. Fototipije izdanja i prateće studije, ur. Đ. Trifunović, Priština, Beograd 2011, 17-39, 117-128]

Пуцић М., Споменици србски, II, Београд 2007². [Pucić M., Spomenici srbski, II, Beograd 20072] Стојановић Љ., Старе српске повеље и писма, I, Београд-Сремски Карловци 1929. [Stojanović, Lj., Stare srpske povelje i pisma, I, Beograd-Sremski Karlovci 1929]

Шуица М., Повеља ияара Уроша о замени поседа између кнеза Војислава и челника Myce, CCA 2 (2003) 144-155. [Šuica M., Povelja cara Urǒ̌a o zameni poseda između kneza Vojislava i čelnika Muse, SSA 2 (2003) 144-155]

\section{Литература - Secondary Works}

Afghah S. M., The Effect of Non-economic Factors in Economic Development in Third World Countries: A Case Study of Iran, PhD Thesis, University of Birmingham, UK, April 1998.

Berk P., Istorija i društvena teorija, Beograd 2002.

Carocci S., Social Mobility and the Middle Ages, Continuity and Change, A Journal of Social Structure, Law and Demography in Past Societies 26 (2011) 367-404.

Clark G., Cummins N., Hao Y., Vidal D. D., Surnames: A New Source for the History of Social Mobility, Explorations in Economic History 55 (2015) 3-24.

Đurović S., Istorija i ekonomske nauke, Treći program Radio Beograda III/2 (1971) 402-405.

Herlihy D., Three Patterns of Social Mobility in Medieval History, The Journal of Interdisciplinary History 3/4 (1973) 623-647.

Hoselitz B. F., Noneconomic Factors in Economic Development, The American Economic Review 47/2 (1957) 28-41.

Katz M. B., Occupational Classification in History, The Journal of Interdisciplinary History 3/1 (1972) 63-88.

Kulischer J., Opća ekonomska povijest srednjega i novoga vijeka, Zagreb 1957.

Long P. O., The Annales and the History of Technology, Annales d'histoire économique et sociale 7 (November 1935), Les techniques, l'histoire et la vie, Technology and Culture 46/1 (2005) 177-186.

J. Lučić, Gospodarsko-drustveni odnosi u Dubrovniku u Stojkovićevo vrijeme (1392-1442), Historijski zbornik 38/1 (1985) 95-114.

Mihaljčić R., Lazar Hrebeljanović. Istorija, kult, predanje, Beograd 1984.

Padgett J., Open Elite? Social Mobility, Marriage, and Family in Florence, 1282-1494, Renaissance Quarterly 63/2 (2010) 357-411.

Pešorda Vardić Z., „Pučka vlastela“: Društvena struktura dubrovačke bratovštine Sv. Antuna u kasnom srednjem vijeku, Povijesni prilozi 33 (2007) 215-236.

Smith M. E., Peasant Mobility, Local Migration and Premodern Urbanization, World Archaeology 46/4 (2014) 516-553.

Sorokin P., Social Mobility, New York-London 1927 (reprint: Taylor \& Francis, 1998)

Social Mobility in Medieval Italy (1100-1500), ed. by S. Carocci and I. Lazzarini, Roma 2018. Spengler J. J., Economic Factors in Economic Development, The American Economic Review 47/2 (1957) 42-56.

Treiman D. J., A Standard Occupational Prestige Scale for Use with Historical Data, The Journal of Interdisciplinary History 7/2 [Social Mobility in Past Time] (1976) 283-304.

Živković P., Ekonomsko socijalne promjene u bosanskom društvu u XIV i XV stoljeću (pojava građanske klase i novog plemstva), Tuzla 1986.

Бродел Ф., Списи о историји, Београд 1992. [Brodel F., Spisi o istoriji, Beograd 1992] 
Веселиновић А., Држава српских деспота, Београд 1995. [Veselinović A., Država srpskih despota, Beograd 1995]

Динић М., Прилози за историју ватреног оружја у Дубровнику и суседним земљама, ГЛАС СКА 161 (1934) 58-97. [Dinić M., Prilozi za istoriju vatrenog oružja u Dubrovniku i susednim zemljama, GLAS SKA 161 (1934) 58-97]

Динић-Кнежевић Д., Миграције становништва из јужнословенских земаља у Дубровник током средњег века, Нови Сад 1995. [Dinić-Knežević D., Migracije stanovništva iz južnoslovenskih zemalja u Dubrovnik tokom srednjeg veka, Novi Sad 1995]

Иванишевић В., Новчарство средњовековне Србије, Београд 2001. [Ivanišević V., Novčarstvo srednjovekovne Srbije, Beograd 2001]

Ивановић М., „Добри људи“ Новобрдског законика деспота Стефана Лазаревића, ИЧ 64 (2015) 159-187. [Ivanović M., „Dobri ljudi“ Novobrdskog zakonika despota Stefana Lazarevića, IČ 64 (2015) 159-187]

Јовановић В., Ћирковић С., Зечевић Е., Иванишевић В., Радић В., Ново Брдо, Београд 2004. [Jovanović V., Ćirković S., Zečević E., Ivanišević V., Radić V., Novo Brdo, Beograd 2004]

Ковачевић-Којић Д., Градски живот у Србији и Босни (XIV-XV), Београд 2007. [Kovačević-Kojić D., Gradski život u Srbiji i Bosni $(X I V-X V)$, Beograd 2007]

Крстић А., Сеоска насеља у Подунављу и Посавини Србије и јужне Угарске у 15. и првој трећини 16. века, ИЧ 52 (2005) 165-194. [Krstić A., Seoska naselja u Podunavlju i Posavini Srbije i južne Ugarske u 15. i prvoj trécini 16. veka, IČ 52 (2005) 165-194]

Крстић А., Деспот Бурађ Вуковић и закуп коморе у Нађбањи, ИЧ 64 (2015) 237-252. [Krstić A., Despot Đurađ Vuković i zakup komore u Nađbanji, IČ 64 (2015) 237-252]

Лапчевић Д., Селски занати и занатлије у Немањићкој држави, Економист - орган Друштва за социјалну и економску политику 5/1 (1925) 15-32. [Lapčević D., Selski zanati i zanatlije u Nemanjićkoj državi, Ekonomist - organ Društva za socijalnu i ekonomsku politiku god. 5/1 (1925) 15-32]

Мргић Ј., Проучавање ,иентралних“ насељь у историјској географији Византијског царства на Балкану и могућности примене нове методологије, Византијски свет на Балкану II, ур. Б. Крсмановић, љ. Максимовић, Р. Радић, Београд 2012, 285-297. [Mrgić J., Proučavanje ,,centralnih “ naselja u istorijskoj geografiji Bizantijskog carstva na Balkanu i mogućnosti primene nove metodologije, Vizantijski svet na Balkanu II, ur. B. Krsmanović, Lj. Maksimović, R. Radić, Beograd 2012, 285-297]

Петровић В., Друштвено раслојавање у српским средњовековним рударским градовима, Наша прошлост 12 (2011) 79-88. [Petrović V., Društveno raslojavanje u srpskim srednjovekovnim rudarskim gradovima, Naša prošlost 12 (2011) 79-88]

Петровић Ђ., Главно оружије епохе и оружари у земљи Стефана Вукчића Косаче, Српска проза данас . Косаче - оснивачи Херцеговине. Ћоровићеви сусрети прозних писаца у Билећи и Научни скуп историчара у Гацку, 20-22. септембар 2000, Билећа, Гацко, Београд 2002, 515-542. [Đ. Petrović, Glavno oružije epohe i oružari u zemlji Stefana Vukčića Kosače, Srpska proza danas . Kosače - osnivači Hercegovine. Ćorovićevi susreti proznih pisaca u Bileći i Naučni skup istoričara u Gacku, 20-22. septembar 2000, Bileća, Gacko, Beograd 2002, 515-542]

Соловјев А., Једна српска жупа за време иарства, Гласник Скопског научног друштва III (1928) 29-33. [A. Solovjev, Jedna srpska župa za vreme carstva, Glasnik Skopskog naučnog društva III (1928) 29-33]

Станић В., Франиуска историографија у XX веку - изазов мултидисииплинарности, Синтезис: часопис за хуманистичке науке и друштвену стварност I/1 (2009) 203-217. [Stanić V., Francuska istoriografija u XX veku-izazov multidisciplinarnosti, Sintezis, časopis za humanističke nauke i društvenu stvarnost I/1 (2009) 203-217] 
Стародубцев Т., Сликари задужбина Лазаревића, ЗРВИ 43 (2006) 359-363. [Starodubcev T., Slikari zadužbina Lazarevića, ZRVI 43 (2006) 359-363]

Томовић Г., Средњовековна мајсторска села на размеђи сеоског и градског друштва, Српско село. Могућности и даљи правци истраживања, Београд 2003, 7-17. [Tomović G., Srednjovekovna majstorska sela na razmeđi seoskog i gradskog društva, Srpsko selo. Mogućnosti i dalji pravci istraživanja, Beograd 2003, 7-17]

Ћирковић С., Сеобе српског народа у краљевину Угарску у XIV и XV веку, Сеобе српског народа од XIV до XX века. Зборник радова посвећен тристогодишњици Велике сеоба Срба, Београд 1990, 37-46. [Ćirković S. Seobe srpskog naroda u kraljevinu Ugarsku u $X I V$ i XV veku, Seobe srpskog naroda od XIV do XX veka. Zbornik radova posvećen tristogodišnjici Velike seoba Srba, Beograd 1990, 37-46]

Ћирковић С., Из старог Дубровника: грађани рођени и грађани стечени, ИЧ 56 (2008) 21-37. [Ćirković S., Iz starog Dubrovnika: građani rođeni i građani stečeni, IČ 56 (2008) 21-37]

Узелац А., Лазар Светогорач - српски монах и часовничар између историје и мита, БИГ 10 (2019) 77-90. [Uzelac A., Lazar Svetogorac-srpski monah i časovničar između istorije i mita, BIG 10 (2019) 77-90]

Фостиков А., Ковачки занат на тлу средњовековне Србије, БИГ 3 (2012) 105-126. [Fostikov A., Kovački zanat na tlu srednjovekovne Srbije, BIG 3 (2012) 105-126]

Фостиков А., Занатство средњовековне Србије у светлу три повеље из 14. века, БИГ 4 (2013) 51-69. [Fostikov A., Zanatstvo srednjovekovne Srbije u svetlu tri povelje iz 14. veka, BIG 4 (2013) 51-69]

Фостиков А., Петровић В., Прилог проучавању војне улоге занатлија у средњовековној Србији, БИГ 5 (2014) 59-69. [Fostikov A., Petrović V., Prilog proučavanju vojne uloge zanatlija u srednjovekovnoj Srbiji, BIG 5 (2014) 59-69]

Фостиков А., Златарски занат у средњовековној Србији, Споменица академика Милоша Благојевића (1930-2012), одг. ур. С. Мишић, Београд 2015, 165-185. [Fostikov A., Zlatarski zanat u srednjovekovnoj Srbiji, Spomenica akademika Miloša Blagojevića (19302012), odg. ur. S. Mišić, Beograd 2015, 165-185]

Фостиков А., Занатство средьовековне Србије, Београд 2020. [Fostikov A., Zanatstvo srednjovekovne Srbije, Beograd 2020] 


\section{Aleksandra Fostikov \\ THE MOBILITY OF CRAFTSMEN IN THE TERRITORY OF MEDIEVAL SERBIA}

\section{Summary}

During the Middle Ages, which belong to the long agrarian age, crafts developed and branched, influencing both the differentiation and stratification of craftsmen. To examine in more detail the mobility of these producers in the territory of medieval Serbia, the existing division of mobility types, harmonised with the given time, was applied to the data from source material. Thus, despite the modest percentage of craftsmen known by name, it was possible to establish that they were mobile. In addition, all types of mobility were present: horizontal, vertical and spatial, as well as intra-generational and inter-generational, though they do not necessarily exclude each other.

The mobility of craftsmen, emergence of free craftsmen and changes in the social structure resulted in new sorts of divisions, also between the craftsmen themselves, who are classified in specific categories depending on their knowledge, skills and financial situation

Чланак примљен: 12. 05. 2020.

Чланак коначно прихваћен за објављивање: 20. 07. 2020. 